Check for updates

Cite this: RSC Adv., 2017, 7, 34676

Received 25th May 2017

Accepted 28th June 2017

DOI: $10.1039 / c 7 r a 05890 j$

rsc.li/rsc-advances

\section{Reversible loading of thiol-modified curcumin in an engineered protein capsid $\dagger$}

\author{
Q. Guo, $\hbar^{a}$ G. C. Thomastit and K. J. Woycechowsky (ID $\S^{\star a b}$
}

The dodecahedral capsid formed by Aquifex aeolicus lumazine synthase (AaLS) is a promising protein scaffold for bionanotechnological applications. A cysteine was installed the inner surface of the AaLS capsid to give a variant (AaLS-IC) that can covalently capture small-molecule thiols in its hollow interior. Cargo loading utilizes a two-stage thiol-disulfide exchange process, involving the initial formation of an activated disulfide adduct between AaLS-IC and 2-nitro-5-thiobenzoate (NTB) followed by displacement of the NTB by an incoming guest molecule. Using a thiol-containing curcumin derivative (cur-SH) as a model guest, we show that about 41 guest molecules can be loaded per capsid. The sequestration of cur-SH inside the capsid increases its solubility in aqueous buffer by more than 30 -fold. Further, the guest can be released upon treatment with tris(2-carboxyethyl)phosphine, which reduces the disulfide bond tethering cur-SH to the capsid. Thus, the AaLS-IC capsid can act as a container for small-molecule thiols, and guest release can be triggered by reducing agents.

\section{Introduction}

Protein capsids can act as nanoscale molecular containers. Such self-assembled structures form a closed shell which encases a hollow interior that can host various guest molecules. ${ }^{1}$ The capsid wall physically separates the guest molecules inside from the bulk environment. ${ }^{2}$ Nature provides a wide array of capsid structures, with diameters ranging from $\sim 10 \mathrm{~nm}$ to $>100 \mathrm{~nm}$ and functions, including storage and transport of nucleic acids (by virus capsids), ${ }^{3}$ metal storage (by ferritin), ${ }^{4}$ and biocatalysis (by bacterial microcompartments, ${ }^{5}$ enapsulin, ${ }^{6}$ and some lumazine synthases $\left.{ }^{7}\right)$. For nanotechnology, protein capsids generally possess several additional desirable traits, such as well-ordered and uniform structures, biocompatibility, and ready modification or functionalization. ${ }^{8,9}$ Consequently, these scaffolds have great potential for applications such as drug delivery, materials synthesis, and the construction of nanoreactors. ${ }^{10-12}$ Nevertheless, the development of general methods for the controlled loading and release of cargo molecules into and out of protein capsids remains an important challenge.

${ }^{a}$ School of Pharmaceutical Science and Technology, Tianjin University, 92 Weijin Road, Nankai District, Tianjin, 300072, China. E-mail: kenneth@tju.edu.cn

${ }^{b}$ Department of Chemistry, University of Utah, 315 South 1400 East, Salt Lake City, UT, 84112, USA

$\dagger$ Electronic supplementary information (ESI) available. See DOI: $10.1039 / \mathrm{c} 7 \mathrm{ra05890j}$

\$ These authors contributed equally to this work.

$\S$ Present address: School of pharmaceutical Science and Technology, Tianjin University, 92 Weijin Road, Nankai District, Tianjin, 300072, China.
Several virus capsids have been repurposed to encapsulate non-native guests. ${ }^{13-16}$ For example, the capsids from bacteriophage MS2,$^{17}$ bacteriophage $\mathrm{Q} \beta,{ }^{18,19}$ bacteriophage $\mathrm{P} 22,{ }^{20}$ polyoma virus, ${ }^{21}$ cucumber mosaic virus,${ }^{22}$ and cowpea chlorotic mottle virus (CCMV $)^{23-25}$ have been loaded with a variety of cargoes, including RNA, proteins, and small molecules. For macromolecular cargoes, like RNA and protein, capsid loading is usually coupled with capsid assembly, since these guests are typically too big to diffuse into the capsid, and encapsulation is driven by non-covalent interactions between the capsid and guest. Small molecules can often be loaded into intact capsids, since virus capsids typically possess pores that allow these cargoes access to the capsid interior. However, small-molecule encapsulation typically requires covalent conjugation of the guest molecule to the inner capsid wall to prevent the guest from simply diffusing back out of the capsid again.

The enzyme lumazine synthase from Aquifex aeolicus (AaLS) has shown much promise as a scaffold for bionanotechnology. The AaLS capsid (Fig. 1A) is built from 60 identical subunits, ${ }^{26}$ which assemble as a dodecamer-ofpentamers. ${ }^{27} \mathrm{~A}$ central tunnel, which is $\sim 0.9 \mathrm{~nm}$ wide at its narrowest point, runs through each of the pentameric building blocks, and potentially provides a means for small molecules to diffuse across the capsid shell. ${ }^{28}$ Compared with viral nanoparticles, the AaLS capsid is relatively small, with an outer diameter of $16 \mathrm{~nm}$ and an inner diameter of $9 \mathrm{~nm}$. Previously, AaLS has been engineered to encapsulate either $\mathrm{RNA}^{29}$ or proteins bearing a high number of positively charged residues, ${ }^{30-34}$ based on charge complementarity strategies. Despite these successes with biomacromolecular 

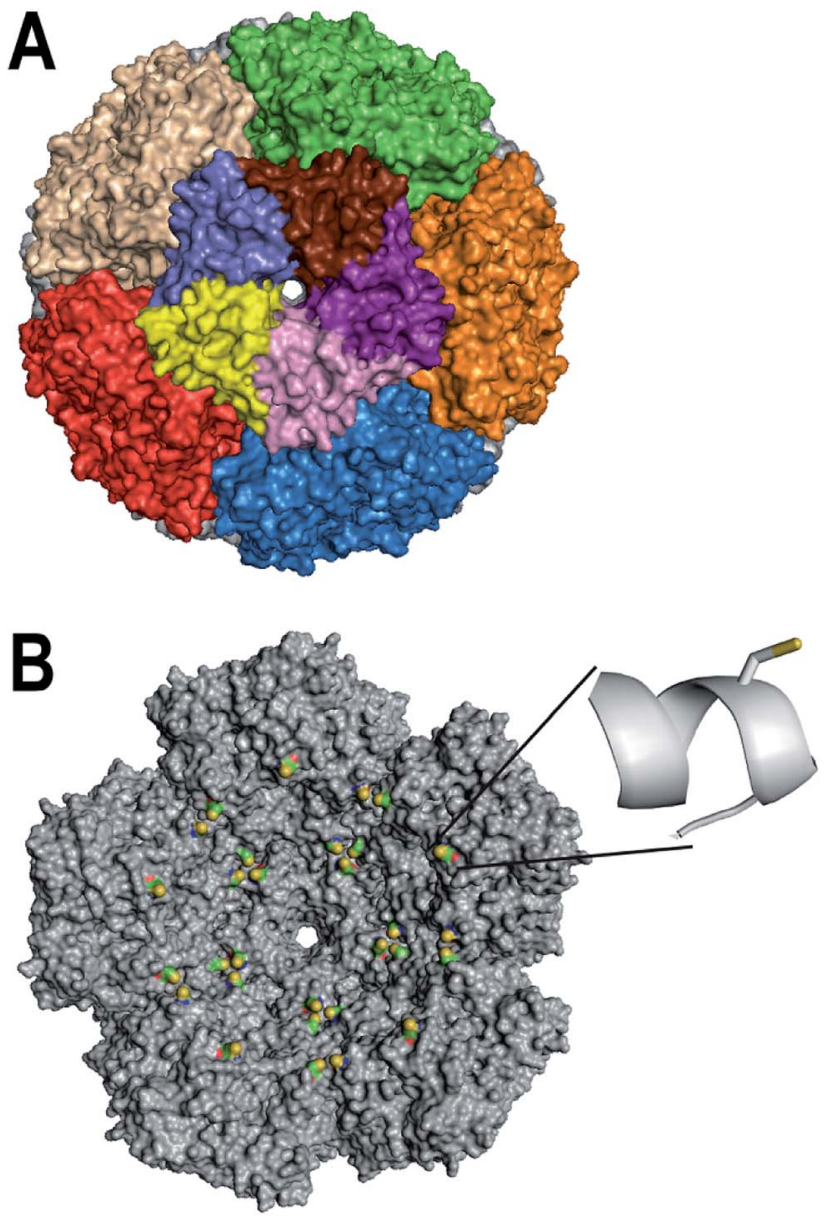

Fig. 1 Design of AaLS-IC. (A) The surface of the AaLS capsid (pdb id: $1 \mathrm{HQK})$ is shown, viewed down one of the five-fold symmetry axes. Individual subunits of the central pentameric building block are individually colored; the other pentamers are each colored uniformly. (B) The interior surface of the rear half of the AaLS capsid is shown. The E122C mutation was modeled using the program Pymol. The engineered cysteines are colored by atom type (sulfur in yellow, carbon in green, oxygen in red, and nitrogen in blue); the rest of the protein is colored gray. The inset shows a close-up of the region around amino acid 122 in which the E122C has been modeled. The side-chain of the engineered cysteine is shown as a stick representation; the protein backbone around it is shown in a ribbon representation.

encapsulation, methods for the encapsulation of small molecules by AaLS are lacking.

Here, we describe a novel AaLS-based system for the controlled encapsulation of small-molecule thiols by the intact capsid. An engineered cysteine was installed at the inner surface of AaLS (Fig. 1B) as a means to capture potential cargo molecules covalently inside the capsid. Using a two-stage thioldisulfide exchange process, we successfully conjugated an analog of the natural product curcumin, as a model guest, to the engineered cysteine via a disulfide linkage. The encapsulated curcumin analog was subsequently released from the capsid by adding a reducing agent. Interestingly, the encapsulated curcumin analog was much more soluble in aqueous buffer than its free counterpart, which could be advantageous for delivery applications.

\section{Materials and methods}

\subsection{Materials}

Curcumin (AR grade) was purchased from Biotopped (Beijing, China) and was purified before use (see below). All other chemicals were of reagent grade or better and used without further purification, unless otherwise noted. Reverse-phase high-performance liquid chromatography (HPLC) separations were performed on an Agilent 1200 HPLC (Agilent, Santa Clara, CA, USA). Determinations of molecular mass were carried out using an Agilent 6310 ion trap mass spectrometer or an Agilent 1260 infinity 6420 triple quad LC/MS. NMR spectroscopy was performed with an $400 \mathrm{MHz}$ Bruker Avance III NMR spectrometer (Bruker, Karlsruhe, Germany). UV-Vis absorbance measurements were made with either a TECAN Infinite M200 Pro plate reader (TECAN, Männedorf, Switzerland), Eppendorf BioPhotometer (Eppendorf, Hamburg, Germany), or a Hitachi U-3900 spectrophotometer (Hitachi High-Tech Science Corporation, Tokyo, Japan). Fluorescence spectroscopy experiments were performed with either the TECAN Infinite M200 plate reader or an FLS 980 fluorimeter (Edinburgh Instruments, Livingston, UK). Protein purifications were carried out using either an AKTA Pure or an AKTA Prime Plus fast protein liquid chromatography instrument (GE Healthcare Life Sciences, Pittsburgh, PA, USA).

\subsection{Site-directed mutagenesis}

To generate a unique cysteine in the AaLS sequence whose side chain should be accessible at the inner capsid surface and be oriented towards the capsid lumen, two successive rounds of site-directed mutagenesis were carried out. In the first round, the naturally occurring cysteine at position 37 was changed to alanine. For this mutagenesis reaction, the plasmid pMG-AaLSnoHis ${ }^{27}$ was used as the template and the primers GT_C37AF and GT_C37AR (5'-GTGGAGGGTGCAATTGATGCTATAGTCCGTCATGGCGGC-3' ${ }^{\prime}$ and $5^{\prime}$-GCCGCCATGACGGACTATAGCATCAATTGCACCCTCCAC- $3^{\prime}$, respectively, mutations indicated in bold) were used to introduce the C37A mutation, yielding plasmid pMG-AaLS-C37A. In a second round of site-directed mutagenesis, glutamate at position 122 was replaced by cysteine. In this case the plasmid pMG-AaLS-C37A was used as the template and the primers GT_E122CF and GT_E122CR (5'-GTTATTACAGCTGA-

CACCTTGTGCCAGGCTATCGAGCGCGCCGGC-3' ${ }^{\prime}$ and $5^{\prime}$-GCCGGCGCGCTCGATAGCCTGGCACAAGGTGTCAGCTGTAATAAC-3', respectively) were used to make the E122C mutation. The resulting plasmid after both rounds of mutagenesis, pMG-AaLSIC, encodes the double variant C37A/E122C-AaLS (AaLS-IC). For both mutations, the mutagenesis PCR was carried out similarly to a previously reported procedure ${ }^{27}$ and involved 18 cycles of denaturation $\left(95{ }^{\circ} \mathrm{C}\right.$ for $\left.30 \mathrm{~s}\right)$, annealing $\left(58{ }^{\circ} \mathrm{C}\right.$ for $\left.30 \mathrm{~s}\right)$, and primer extension $\left(72{ }^{\circ} \mathrm{C}\right.$ for $\left.6 \mathrm{~min}\right)$. The coding portions of the resulting plasmids (pMG-AaLS-C37A and pMG-AaLS-IC) were confirmed by DNA sequencing (University of Utah DNA sequencing core facility). 


\subsection{Production and purification of AaLS-IC}

AaLS-IC capsids were produced in Escherichia coli BL21 (DE3) cells from plasmid pMG-AaLS-IC and purified using a combination of ammonium sulfate treatment, anion exchange chromatography, and size-exclusion chromatography, according to a previously published procedure. ${ }^{27}$ The purity of each protein was confirmed by SDS-PAGE. The yield was determined by Bradford assay. The typical yield of pure AaLS-IC was $\sim 20 \mathrm{mg}$ $\mathrm{L}^{-1}$ of cell culture.

\subsection{Synthesis of cur-SH}

The curcumin used for this derivatization was purified by silica gel chromatography using $\mathrm{CH}_{2} \mathrm{Cl}_{2}$ as the mobile phase. Purified curcumin gave a single spot with an $R_{\mathrm{f}}$ value of 0.5 by thin-layer chromatography using 1,2-dichloroethane : methanol (20:1, v/ v) as the mobile phase. Purified curcumin was derivatized using a previously reported procedure ${ }^{35}$ to generate cur-SS-COOH (Fig. 2). The crude product was re-dissolved in dichloromethane ( $4 \mathrm{~mL}$ ) and purified by silica gel column chromatography using 1,2-dichloroethane : methanol : acetic acid (98:0.98:1, v/v) as the mobile phase. Individual fractions were analyzed by thinlayer chromatography using 1,2-dichloroethane : methanol :acetic acid ( $90: 3: 0.93, \mathrm{v} / \mathrm{v}$ ) as the developing solvent. The $R_{\mathrm{f}}$ value of the desired singly modified curcumin product is about 0.27 . The mass of the purified product was $0.16 \mathrm{~g}$ ( $28 \%$ yield). The structure of this product was confirmed by ${ }^{1} \mathrm{H}$ and ${ }^{13} \mathrm{C}$ NMR (400 MHz, $\mathrm{CDCl}_{3}$ ) spectroscopy. ${ }^{1} \mathrm{H} \mathrm{NMR}, \delta[\mathrm{ppm}]: 7.63-7.57(\mathrm{~m}$, 2H), 7.14-6.92 (m, 6H), 6.57-6.47 (m, 2H), $5.83(\mathrm{~s}, 1 \mathrm{H}), 3.94(\mathrm{~s}$, $3 \mathrm{H}), 3.88$ (s, 3H), 3.07-3.05 (m, 4H), 3.00-2.96 (t, 2H), 2.85-2.81 $(\mathrm{t}, 2 \mathrm{H}) .{ }^{13} \mathrm{C}$ NMR, $\delta[\mathrm{ppm}]: 184.64,181.77,169.73,151.25$, $148.07,146.87,141.26,140.99,139.35,134.19,127.52,124.30$, 123.16, 123.07, 121.71, 120.95, 114.92, 111.50, 109.78, 101.59,

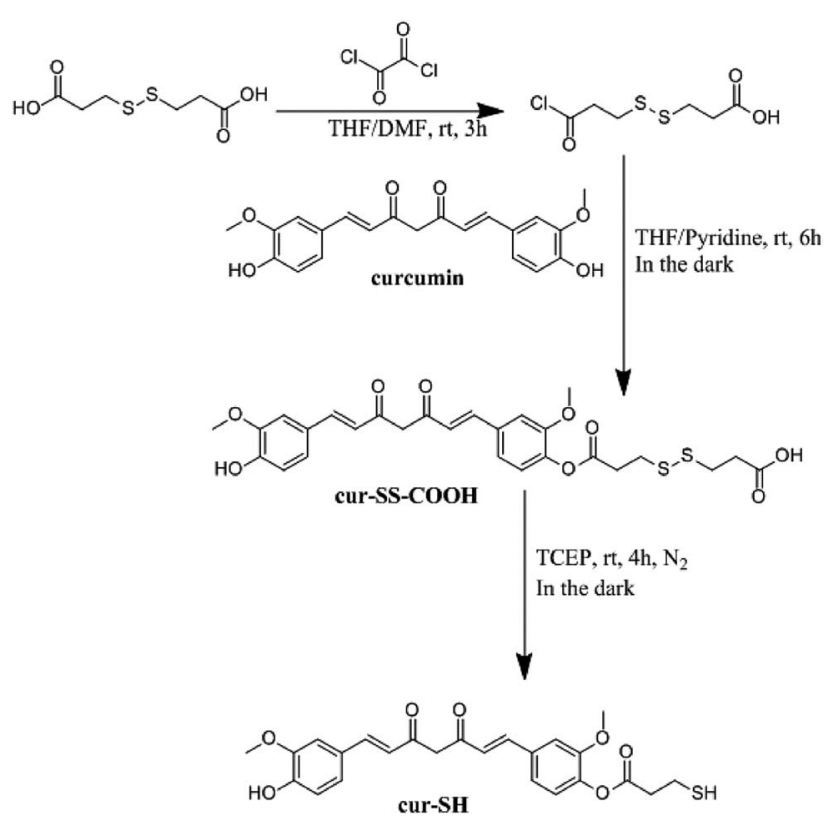

Fig. 2 Synthetic scheme for the derivatization of curcumin to make cur-SH.
55.96, 55.93, 43.51, 33.91, 33.05, 29.71, 22.73. IR (KBr) $\mathrm{cm}^{-1}$ : 3600-3900 (broad, m), 3000-3300 (broad, m), 1754 (w), 1629 (w), 1581 (w), 1511 (s), 1384 (w), 1123 (m). MS (ESI) calculated for $\left[\mathrm{C}_{27} \mathrm{H}_{27} \mathrm{O}_{9} \mathrm{~S}_{2}\right]^{-}$559.12, observed 559.1.

Cur-SS-COOH contains a disulfide bond which was reduced to generate the thiol-curcumin derivate used for loading into the AaLS-IC capsid. This reduction was carried out by first dissolving the disulfide-containing curcumin derivative $(0.1 \mathrm{mmol}$, $57.8 \mathrm{mg})$ in THF $(20 \mathrm{~mL})$ and then adding $183 \mathrm{mM}$ aqueous tris(2-carboxyethyl)phosphine (TCEP) (3 $\mathrm{mL})$. The reaction mixture was incubated at room temperature under $\mathrm{N}_{2}$ and in the dark for $4 \mathrm{~h}$. The solvent was then removed by rotary evaporation and the resulting orange solid was purified using silica gel column chromatography using a solvent system consisting of 1,2-dichloroethane : methanol : acetic acid (98: $0.98: 1, \mathrm{v} / \mathrm{v})$. Individual fractions were analyzed by thinlayer chromatography using 1,2-dichloroethane : methanol :acetic acid (90:3:0.93, v/v) as the developing solvent. The $R_{\mathrm{f}}$ value of cur-SH is about 0.6 . The collected product has a mass of $7 \mathrm{mg}$ (15\% yield). Cur-SH (7 mg) was then dissolved in acetonitrile $(1 \mathrm{~mL})$, passed through a $0.22 \mu \mathrm{M}$ nylon syringe filter, and further purified by reverse-phase HPLC using an Agilent 1260 infinity HPLC system equipped with a SunFire Prep C8 column $(19 \times 250 \mathrm{~mm}, 5 \mu \mathrm{M}$ particle size, OBD $)$. The HPLC purification was carried out at $40{ }^{\circ} \mathrm{C}$ under isocratic conditions using a solvent system consisting of acetonitrile : water : formic acid $(50: 50: 0.1)$ and at a flow rate of $10 \mathrm{~mL} \mathrm{~min}^{-1}$. The detection wavelength was $210 \mathrm{~nm}$. Cur-SH eluted as the main peak with an elution time of $7.23 \mathrm{~min}$. The material corresponding to this peak was collected. The final isolated yield of cur-SH was $5 \mathrm{mg}$. The resulting orange-yellow solid was confirmed to be cur-SH by ${ }^{1} \mathrm{H}$ and ${ }^{13} \mathrm{C}$ NMR spectroscopy (400 $\left.\mathrm{MHz}, \mathrm{CDCl}_{3}\right) \cdot{ }^{1} \mathrm{H} \mathrm{NMR}$, $\delta[\mathrm{ppm}]:$ 7.54-7.51 (m, 2H), 7.06-6.87 (m, 6H), 6.49-6.41 (m, $2 \mathrm{H}), 5.76(\mathrm{~s}, 2 \mathrm{H}), 3.87(\mathrm{~s}, 3 \mathrm{H}), 3.80(\mathrm{~s}, 3 \mathrm{H}), 2.88(\mathrm{t}, 1 \mathrm{H}), 2.82(\mathrm{~m}$, $1 \mathrm{H}), 1.74(\mathrm{t}, 1 \mathrm{H}) .{ }^{13} \mathrm{C} \mathrm{NMR}, \delta[\mathrm{ppm}]: 184.59,181.76,169.57$, $151.26,148.04,146.84,141.22$, 140.97, 139.34, 134.24, 127.55, $124.35,123.22$, 123.07, 121.76, 120.98, 114.89, 111.45, 109.70, 101.59, 55.98, 55.92, 38.37, 19.85. IR (KBr) cm $\mathrm{cm}^{-1}: 3002$ (s), 2882 (s), $2811(\mathrm{~s}), 1578(\mathrm{~m}), 1543(\mathrm{~m}), 1510(\mathrm{~m}), 1476(\mathrm{~m}), 1420(\mathrm{w})$, $1386(\mathrm{w})$. MS (ESI) calculated for $\left[\mathrm{C}_{24} \mathrm{H}_{25} \mathrm{O}_{7} \mathrm{~S}\right]^{+}[\mathrm{M}+\mathrm{H}]^{+} 457.1$, observed 457.5; calculated for $\left[\mathrm{C}_{24} \mathrm{H}_{23} \mathrm{O}_{7} \mathrm{~S}\right]^{-}[\mathrm{M}-\mathrm{H}]^{-}$455.1, observed 455.0 .

\subsection{Conjugation of cur-SH to AaLS-IC}

Loading of cur-SH into AaLS-IC capsids was carried out via a two-stage thiol-disulfide exchange process. AaLS-IC ( $3 \mathrm{~mL}$ of a $1 \mathrm{mg} \mathrm{mL}{ }^{-1}$ solution) was slowly added dropwise with stirring into a solution $(353 \mu \mathrm{L})$ containing $5 \mathrm{mM}$ 5,5'-dithiobis-(2nitrobenzoic acid) (DTNB). Both reactants (AaLS-IC and DTNB) were dissolved in SEC buffer $(50 \mathrm{mM}$ sodium phosphate, $200 \mathrm{mM} \mathrm{NaCl}, \mathrm{pH}$ 8.0). The final concentration of AaLS-IC was $53 \mu \mathrm{M}$; the final concentration of DTNB was $530 \mu \mathrm{M}$. The reaction was incubated at room temperature for $20 \mathrm{~min}$. The solution immediately turned bright yellow, indicating disulfide bond formation between the cysteine of AaLS-IC and one half of DTNB with concomitant release of NTB (the other half of 
DTNB). The concentration of NTB released can be calculated by measuring the absorbance at $412 \mathrm{~nm}\left(\varepsilon_{412} \mathrm{~nm}=14150 \mathrm{M}^{-1}\right.$ $\left.\mathrm{cm}^{-1}\right) .{ }^{36}$ The product mixture was dialyzed into fresh SEC buffer $(1 \mathrm{~L})$ overnight at $4{ }^{\circ} \mathrm{C}$ in the dark to remove the free NTB and unreacted DTNB. Cur-SH $\left(660 \mu \mathrm{L}\right.$ of a $0.17 \mathrm{mg} \mathrm{mL}^{-1}$ solution, dissolved in ethanol and kept in the dark) was slowly added to the AaLS-IC-NTB conjugate $\left(6 \mathrm{~mL}\right.$ of a $0.5 \mathrm{mg} \mathrm{mL}{ }^{-1}$ solution, dissolved in SEC buffer), which resulted in a two-fold molar excess of cur-SH over AaLS-IC-NTB. The final concentration of ethanol in the reaction was $10 \%(\mathrm{v} / \mathrm{v})$. The reaction was incubated at room temperature for $20 \mathrm{~min}$ in the dark. Since both curcumin and NTB have strong absorbance at $412 \mathrm{~nm}$, the amount of NTB released was calculated by measuring the $\Delta A_{412 \mathrm{~nm}}$, since the $\varepsilon_{412 \mathrm{~nm}}$ of cur$\mathrm{SH}$ should not change significantly between the thiol and disulfide forms. Before measuring the absorbance, an aliquot of the product mixture was diluted five-fold with SEC buffer, so that the final concentration of ethanol is $2 \%(\mathrm{v} / \mathrm{v})$. The $\Delta A_{412 \mathrm{~nm}}$ was calculated by subtracting the $A_{412} \mathrm{~nm}$ of $3.4 \mu \mathrm{g} \mathrm{mL}{ }^{-1}$ unreacted cur-SH (corresponding to a 50-fold dilution of the original $0.17 \mathrm{mg}$ $\mathrm{mL}^{-1}$ cur-SH stock solution into SEC buffer) from the $A_{412} \mathrm{~nm}$ of the product mixture. For all subsequent experiments, the remaining crude product mixture was dialyzed into SEC buffer (2 L) overnight at $4{ }^{\circ} \mathrm{C}$ in the dark.

\subsection{UV-Vis spectroscopy}

Since curcumin has a distinct absorbance spectrum from the AaLS-IC protein, UV-Vis spectroscopic analysis was carried out on the AaLS-IC-cur conjugate. The absorbance of AaLS-IC-cur $(8 \mu \mathrm{M})$ in SEC buffer with $2 \%$ ethanol $(200 \mu \mathrm{L}$ final volume) was measured from $600 \mathrm{~nm}$ to $300 \mathrm{~nm}$ in $1 \mathrm{~nm}$ increments using a TECAN plate reader and a flat-bottomed polystyrene 96-well plate (Jet Biofil, Guangzhou, China). SEC buffer with $2 \%$ ethanol was used as the blank. UV-Vis absorbance spectra of AaLS-ICNTB conjugate $(8 \mu \mathrm{M})$ and free cur-SH $(5.8 \mu \mathrm{M})$ were obtained in the same way, as controls.

\subsection{Fluorescence spectroscopy}

Since curcumin is fluorescent, fluorescence spectroscopy was used to further characterize the AaLS-IC-cur conjugate. The fluorescence spectrum of AaLS-IC-cur $(8 \mu \mathrm{M})$ in SEC buffer with $2 \%$ ethanol was obtained by measuring the emission from $422 \mathrm{~nm}$ to $600 \mathrm{~nm}$ in $1 \mathrm{~nm}$ increments, after excitation at $412 \mathrm{~nm}$. Fluorescence spectra of AaLS-IC-NTB $(8 \mu \mathrm{M})$ and free cur-SH $(5.8 \mu \mathrm{M})$ were also measured in the same way, as controls.

\subsection{Size-exclusion chromatography analysis of AaLS-IC-cur}

To verify the attachment of cur-SH (a small molecule) to AaLS-IC (a large protein), the AaLS-IC-cur conjugate was subjected to analytical SEC. The $A_{280} \mathrm{~nm}$ and curcumin-based fluorescence were then measured for each individual fraction. Prior to SEC analysis, the conjugate was concentrated by ultrafiltration using a VIVASPIN 20 (30 $000 \mathrm{MWCO}$ ) spin concentrator (Sartorius) to a final concentration of $2.5 \mathrm{mg} \mathrm{mL}^{-1}$ and then passed through a $0.22 \mu \mathrm{m}$ syringe filter. The AaLS-IC-cur was then loaded onto an AKTA Pure system equipped with a Hiprep 16/60 sephacryl S-
$400 \mathrm{HR}$ column. The running buffer, flow rate, and temperature were the same as described above for the purification of AaLSIC. Immediately after the sample was injected onto the column, fractions ( $4 \mathrm{~mL}$ each) were collected over a total eluent volume of $120 \mathrm{~mL}$. For each fraction, the $A_{280} \mathrm{~nm}$ and fluorescence emission at $525 \mathrm{~nm}\left(\lambda_{\text {excitation }}=412 \mathrm{~nm}\right)$ were recorded.

\subsection{HPLC of AaLS-IC-cur}

Analytical reverse-phase HPLC was used to check for noncovalently bound cur-SH in the AaLS-IC-cur sample. To prepare the AaLS-IC-cur for HPLC analysis, the conjugate was dialyzed into PBS buffer containing $10 \mathrm{mM}$ sodium phosphate, $2 \mathrm{mM}$ potassium phosphate, $150 \mathrm{mM} \mathrm{NaCl}$, and $3 \mathrm{mM} \mathrm{KCl}$ at $\mathrm{pH}$ $7.4(1 \mathrm{~L})$ overnight at $4{ }^{\circ} \mathrm{C}$ in the dark, concentrated by ultrafiltration to a final protein concentration of $\sim 2 \mathrm{mg} \mathrm{mL}^{-1}$, diluted with pure water to a final protein concentration of $0.2 \mathrm{mg} \mathrm{mL} \mathrm{m}^{-1}$, and then filtered with a $0.22 \mu \mathrm{M}$ nylon membrane. AaLS-IC-cur $(20 \mu \mathrm{L})$ was then injected onto a HPLC system equipped with a Thermo Biobasic C4 column $(150 \mathrm{~mm} \times 4.6$ $\mathrm{mm}, 5 \mu \mathrm{m}$ particle size, $30 \mathrm{~nm}$ pore size) and a diode array detector. The HPLC running conditions were $25{ }^{\circ} \mathrm{C}, 1 \mathrm{~mL} \mathrm{~min}{ }^{-1}$ flowrate; the detection wavelength was $410 \mathrm{~nm}$. AaLS-IC-cur was eluted from the column using a gradient from $5: 95: 0.05$ (acetonitrile : water : formic acid) to $95: 5: 0.05$ (acetonitrile : water : formic acid) over $20 \mathrm{~min}$.

\subsection{Reductive release of cur-SH from AaLS-IC-cur}

The ability of the reducing agent TCEP to release cur-SH from the conjugate was examined using reverse-phase HPLC. AaLSIC-cur was prepared for the reaction by dialysis into PBS and ultrafiltration, as described above. TCEP $(1.6 \mu \mathrm{L}$ of a $125 \mathrm{mM}$ stock solution in PBS) was added to five aliquots (38.4 $\mu \mathrm{L}$ each) of AaLS-IC-cur (2.3 $\mathrm{mg} \mathrm{mL}^{-1}$ protein, $90.5 \mu \mathrm{M}$ curcumin). The final concentration of TCEP in these aliquots was $5 \mathrm{mM}$. The aliquots were incubated at $4{ }^{\circ} \mathrm{C}$ in the dark. At certain time points following the addition of TCEP $(0.5 \mathrm{~h}, 1 \mathrm{~h}, 2 \mathrm{~h}, 4 \mathrm{~h}$, and 8 h), $0.05 \%$ formic acid in acetonitrile $(160 \mu \mathrm{L})$ was added to a single aliquot to dissolve precipitated free cur-SH. The sample was then filtered through a $0.22 \mu \mathrm{m}$ nylon membrane and then immediately injected ( $20 \mu \mathrm{L}$ injection volume) onto an HPLC system equipped with a Thermo Biobasic C4 column and a diode array detector. Free cur-SH was separated from the protein and other components of the reaction mixture using a gradient from $5 \%$ acetonitrile $/ 95 \%$ water $/ 0.05 \%$ formic acid to $95 \%$ acetonitrile $/ 5 \%$ water $/ 0.05 \%$ formic acid over $20 \mathrm{~min}$

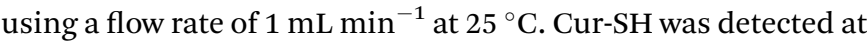
$410 \mathrm{~nm}$. PBS $(1.6 \mu \mathrm{L})$ was added to seven additional aliquots of AaLS-IC-cur, which were treated and analyzed in the same fashion as the other aliquots. Five of these additional aliquots served as negative controls for cur-SH release for each of the above time points. The remaining two TCEP-free aliquots were analyzed immediately and used to represent the $0 \mathrm{~h}$ time point. Time courses of the reaction between TCEP and AaLS-IC-cur were performed in triplicate. Reductive release of cur-SH from AaLS-IC was also carried out at a higher concentration of TCEP (10 $\mathrm{mM}$ ), using essentially the same procedure, but with 
a slightly different concentration of AaLS-IC-cur conjugate ( $2 \mathrm{mg} \mathrm{mL} \mathrm{m}^{-1}$ protein, $76.5 \mu \mathrm{M}$ curcumin).

The concentration of free cur-SH in each sample was determined by integrating the appropriate peak in the HPLC chromatogram $(15.2 \mathrm{~min})$ and comparing the peak area to a calibration curve. To obtain the calibration curve, different concentrations of free cur-SH $(0.39 \mu \mathrm{M}$ to $50 \mu \mathrm{M})$ were prepared by two-fold serial dilutions of a $50 \mu \mathrm{M}$ cur-SH stock solution in acetonitrile. Following filtration through a 0.22 $\mu \mathrm{m}$ nylon membrane, each cur-SH standard was subjected to the same HPLC conditions as described above for the release reaction. The volume of each injection was $20 \mu \mathrm{L}$. The areas of the $A_{410 \mathrm{~nm}}$ peaks at $15.2 \mathrm{~min}$ were then plotted against the concentration of cur-SH and fit to a linear equation using the program OriginPro 2015 (OriginLab, Northampton, MA, USA). The data were linear over the entire concentration range $\left(r^{2}=0.9958\right)$. The free cur-SH concentration at each time point was corrected for the non-covalently bound cur-SH present in the AaLS-IC-cur conjugate by subtracting the free cur-SH concentration of the corresponding sample lacking TCEP.

\subsection{Stability of cur-SH}

Curcumin is known to degrade slowly in aqueous buffers and in the presence of thiols. ${ }^{37}$ To check for curcumin degradation under the experimental conditions, the loss of absorbance by cur-SH was measured over time. TCEP $(160 \mu \mathrm{L}$ of a $250 \mathrm{mM}$ stock solution in water) was added to a solution containing 19 $\mu \mathrm{M}$ cur-SH dissolved in $90 \%$ SEC buffer $/ 10 \%$ ethanol $(3840 \mu \mathrm{L})$. The final concentration of TCEP was $10 \mathrm{mM}$ and the final volume was $4 \mathrm{~mL}$. After mixing, the $A_{412} \mathrm{~nm}$ was measured for $2 \mathrm{~h}$. As a control, another sample was prepared and analyzed in the same way, except that SEC buffer $(160 \mu \mathrm{L})$ was added instead of TCEP.

\section{Results and discussion}

\subsection{Design \& production of AaLS-IC}

Disulfide bonds are useful linkages for conjugating small molecules to proteins. To enable disulfide conjugation at the interior surface of the AaLS capsid, two point mutations (C37A/E122C) were made in order to remove a naturallyoccurring cysteine and to introduce a new one in the desired location. Visual inspection of the AaLS structure (Fig. 1B) suggested that the side-chain of the engineered cysteine at position 122, which is located in the middle of an $\alpha$-helix, should be oriented toward the capsid lumen and thus be accessible for reaction with molecules that diffuse into the interior space. The resulting variant (AaLS-IC) was produced in Escherichia coli BL21 (DE3) cells and purified by ammonium sulfate treatment, anion exchange chromatography, and size-exclusion chromatography (SEC), yielding about $20 \mathrm{mg}$ of pure protein per $\mathrm{L}$ of cell culture. The mutations do not noticeably affect the capsid assembly, as assessed by analytical SEC (Fig. S1 $\dagger$ ) and transmission electron microscopy (Fig. S2 $\dagger$ ).

\subsection{Synthesis \& loading of AaLS-IC}

Small molecules containing a thiol group can potentially be loaded into the AaLS-IC capsid by disulfide bond formation. Towards this end, a derivative of curcumin containing a thiol group (cur-SH) (Fig. 2) was synthesized by a three-step process. Cur-SH represents an appealing model guest because curcumin is fluorescent ${ }^{38}$ and there has been great recent interest in developing vehicles for the delivery of curcumin into cells that can overcome its low bioavailability. ${ }^{39-41}$

Cur-SH can be loaded into the AaLS-IC capsid using a twostage thiol-disulfide exchange reaction involving reduction of DTNB via the formation of an intermediate containing a mixed disulfide bond between the AaLS-IC protein and 2-nitro-5thiobenzoic acid (NTB) (Fig. 3). Upon addition of DTNB, a bright yellow color formed instantaneously, which was accompanied by the appearance of a large new peak in the UVVis spectrum at $412 \mathrm{~nm}$ (Fig. S3†). This color change is characteristic of the specific reaction between cysteine thiols and DTNB. ${ }^{42}$ Upon removal of the unreacted DTNB and the free NTB product, the spectrum of the AaLS-IC-NTB product revealed a new shoulder at $330 \mathrm{~nm}$, which can be attributed to the formation of a mixed disulfide between NTB and AaLS-IC. The yield of AaLC-IC-NTB conjugate in the first stage was $71 \%$, as assessed by UV-Vis spectroscopy (Table $\mathrm{S} 1 \dagger$ ).

The disulfide bond in this intermediate is activated for reaction with incoming thiols, as NTB is a good leaving group. Indeed, during the second stage, the addition of cur-SH to AaLSIC-NTB led to rapid displacement of NTB, forming the desired AaLS-IC-cur conjugate with a $96 \%$ yield (Table S2 $\dagger$ ). The overall yield for these two steps indicates that about 41 cur-SH molecules were conjugated per capsid.

Following the removal of free NTB and unreacted cur-SH by dialysis, the AaLS-IC-cur conjugate was characterized by UVVis spectroscopy and fluorescence spectroscopy. Natural curcumin and the cur-SH derivative have similar UV-Vis absorbance and fluorescence emission spectra, although $\lambda_{\max }$ is about 7-10 $\mathrm{nm}$ lower for cur-SH (Fig. S4 $\dagger$ ). The UV-Vis spectrum of AaLS-IC-cur showed a large absorbance peak at $410 \mathrm{~nm}$ (Fig. 4), similar to that of curcumin ${ }^{43,44}$ and cur-SH, but absent from the AaLS-IC-NTB intermediate. The fluorescence spectrum of AaLS-IC-cur showed a large emission peak at $525 \mathrm{~nm}$ (Fig. 5), which is characteristic of curcumin ${ }^{43,44}$ and cur-SH but not AaLS-IC-NTB. Together, these spectra are consistent with what would be expected for the desired AaLSIC-cur conjugate. SEC analysis shows that the AaLS-IC-cur conjugate elutes as a single peak with the same elution volume as the unreacted AaLS-IC capsid, indicating that curcumin loading does not change the assembly state of AaLS-IC (Fig. 6). Further, during SEC the curcumin-based fluorescence co-elutes with the capsid protein, signifying that the cur-SH is attached to the protein. AaLS-IC-cur was also subjected to reverse-phase HPLC analysis. The resulting chromatogram (Fig. 7) showed a large peak with a retention time of $18 \mathrm{~min}$, which is about 3 minutes later than the elution time of free cur-SH. A small peak was observed at $15.2 \mathrm{~min}$, similar to free cur-SH, but this species represents only about $5 \%$ of the total 
A

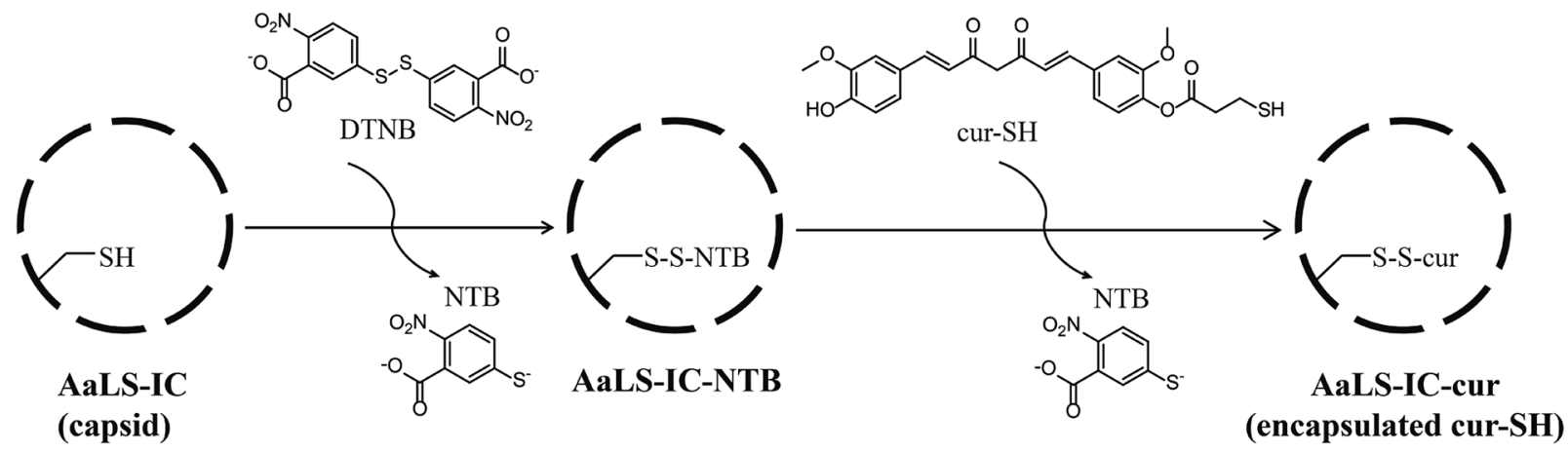

B

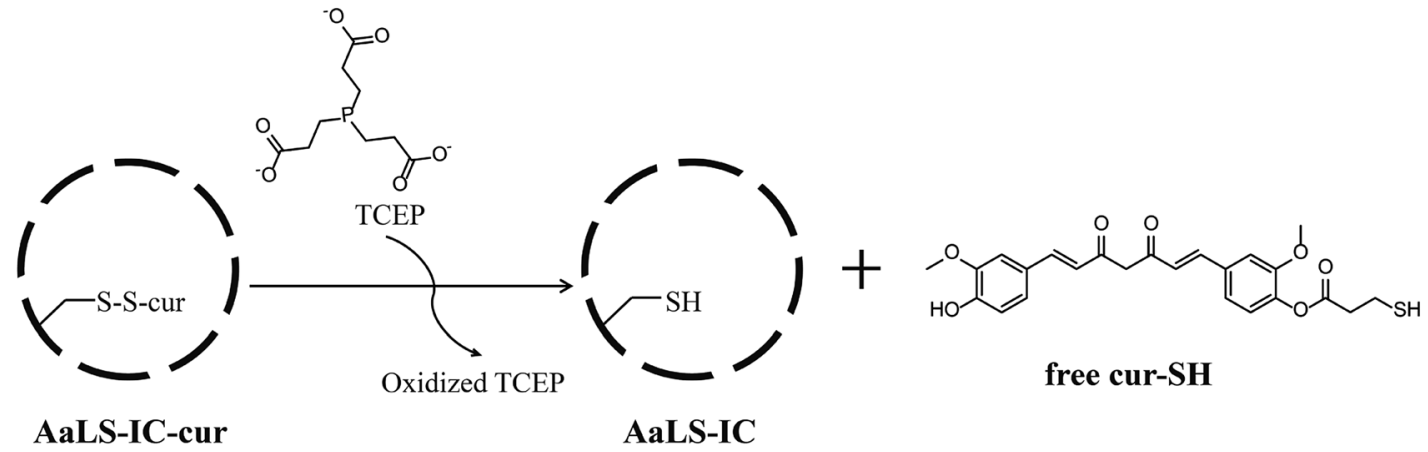

Fig. 3 Scheme for loading and unloading of AaLS-IC with cur-SH. (A) Cur-SH can be loaded into the intact AaLS-IC capsid by a two-stage thioldisulfide exchange reaction at the engineered cysteine on the inner capsid surface, yielding a disulfide bonded conjugate (AaLS-IC-cur) between cur-SH and AaLS-IC. (B) The disulfide bond between cur-SH and AaLS-IC can be broken by the reducing reagent TCEP, allowing free cur-SH to be released from the capsid.

curcumin in the sample, or about 2 cur-SH molecules per capsid. This free cur-SH observed in the chromatogram can be attributed to non-covalently bound cur-SH that is released from the protein under the denaturing conditions of the reverse-phase HPLC analysis.

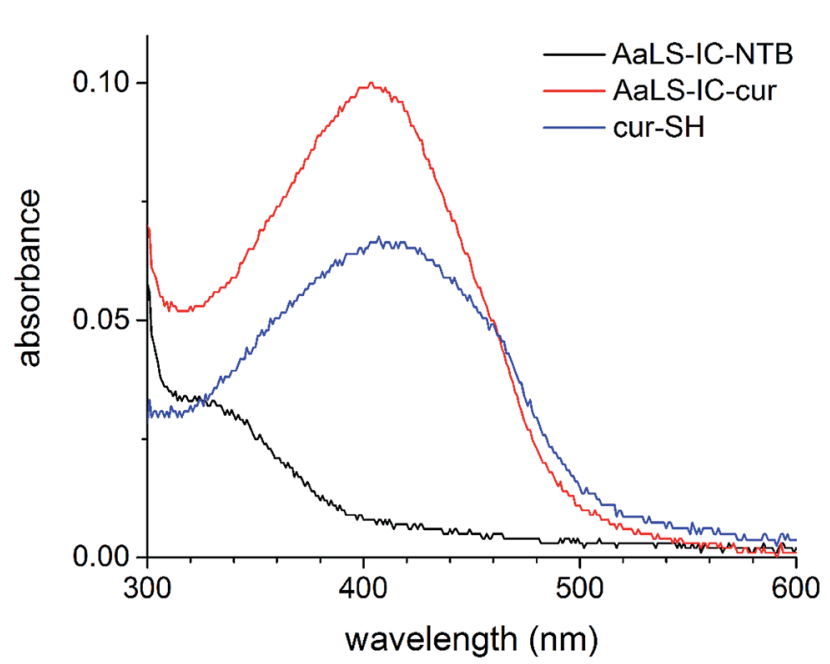

Fig. 4 UV-Vis spectra of cur-SH, AaLS-IC-NTB and AaLS-IC-cur. The absorbance of AaLS-IC-cur (red), AaLS-IC-NTB (black), and cur-SH (blue) in SEC buffer with 2\% ethanol were measured from $600 \mathrm{~nm}$ to $300 \mathrm{~nm}$. SEC buffer with $2 \%$ ethanol was used as the blank. The concentrations of AaLS-IC-cur, AaLS-IC-NTB, and cur-SH were $8 \mu \mathrm{M}$, $8 \mu \mathrm{M}$, and $5.8 \mu \mathrm{M}$, respectively.

\subsection{Solubility of AaLS-IC-cur}

Curcumin is notoriously insoluble in aqueous solution. However, the sequestration of curcumin inside the AaLS capsid should prevent the encapsulated curcumin from aggregating

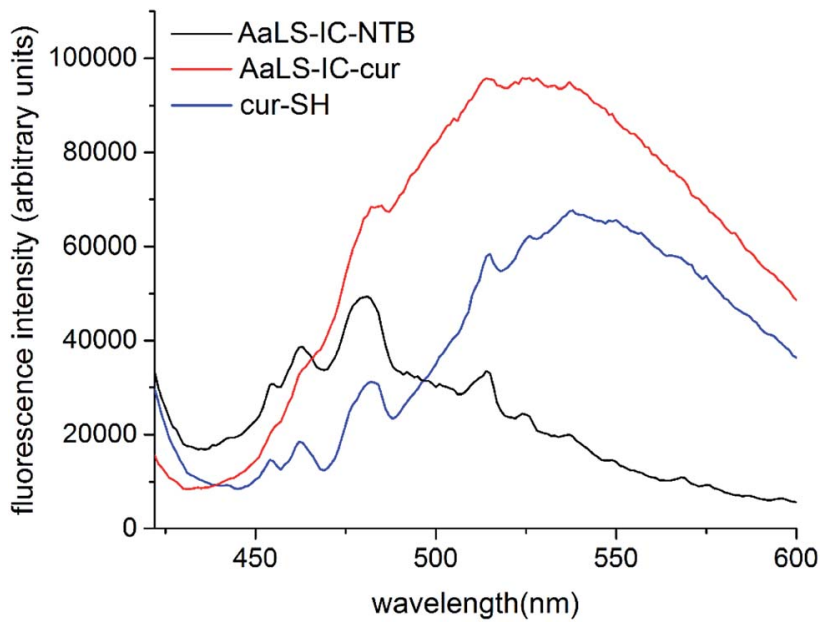

Fig. 5 Fluorescence spectra of cur-SH, AaLS-IC-NTB and AaLS-ICcur. The fluorescence emission of AaLS-IC-cur (red), AaLS-IC-NTB (black), and cur-SH (blue) in SEC buffer with $2 \%$ ethanol were measured from $422 \mathrm{~nm}$ to $600 \mathrm{~nm}$, after excitation at $412 \mathrm{~nm}$. SEC buffer with $2 \%$ ethanol was used as the blank. The concentrations of AaLS-IC-cur, AaLS-IC-NTB, and cur-SH were $8 \mu \mathrm{M}, 8 \mu \mathrm{M}$, and $5.8 \mu \mathrm{M}$, respectively. 


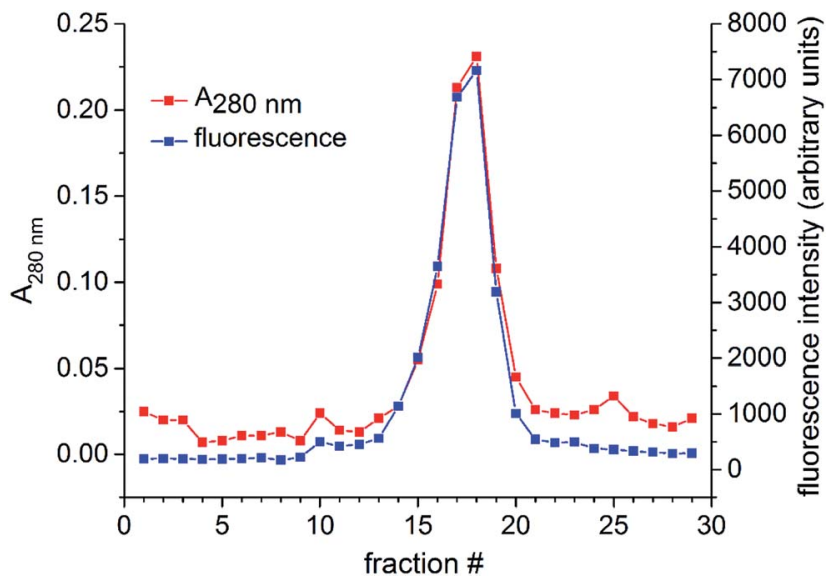

Fig. 6 SEC analysis of AaLS-IC-cur. The AaLS-IC-cur conjugate was injected onto a Hiprep 16/60 sephacryl S-400HR column and eluted over a total volume of $120 \mathrm{~mL}$. The $A_{280} \mathrm{~nm}$ and fluorescence emission at $525 \mathrm{~nm}$ (excitation at $412 \mathrm{~nm}$ ) were then measured for each of the individual fractions. The size of each fraction was $4 \mathrm{~mL}$.

and precipitating. To test whether the encapsulation of curcumin increases its solubility in PBS buffer containing $0.8 \%$ ethanol, samples of both AaLS-IC-cur and free cur-SH, each containing a total amount of curcumin that would correspond to a concentration of $30 \mu \mathrm{M}$ (if fully soluble), were analyzed by subjecting them to centrifugation (to pellet any insoluble material) and measuring the absorbance values of the supernatants at $412 \mathrm{~nm}$ (to provide a relative estimate of the curcumin remaining in solution). Indeed, the $A_{412}$ of AaLS-IC-cur, which did not produce a visible pellet, was double that of free cur-SH, which gave a yellow pellet. The AaLS-IC-cur sample was then further concentrated by ultrafiltration and the analysis was repeated. For total curcumin concentrations as high as $430 \mu \mathrm{M}$, precipitation was still not evident and the $A_{412}$ value increased proportionately (Table 1). Thus, the curcumin in AaLS-IC-cur is $>30$-fold more soluble in buffer than free cur-SH. At the highest concentration of AaLS-IC-cur tested, the total protein concentration is $\sim 10 \mathrm{mg} \mathrm{mL}^{-1}$, and the solubility limit had still not been reached.

The poor solubility of curcumin in aqueous media contributes to its low bioavailability. ${ }^{45}$ The aqueous solubility of natural curcumin has been reported to be $30 \mathrm{nM} .^{38}$ After dialysis into pure water, AaLS-IC-cur also remained soluble up to a total curcumin concentration of $430 \mu \mathrm{M}$ (Table S3†). Thus the solubility of cur-SH encapsulated by AaLS-IC is $>14$ 000-fold higher than that of the free natural product in water. The increased solubility of encapsulated cur-SH might also improve the bioavailability of this potential drug.

\subsection{Release of cur-SH}

Reduction of the disulfide bond connecting cur-SH to the AaLSIC protein should allow release of the cur-SH cargo from the capsid. This disulfide bond should be sensitive to smallmolecule reducing agents. To test this hypothesis, AaLS-ICcur was treated with TCEP. Analysis of this reaction at different
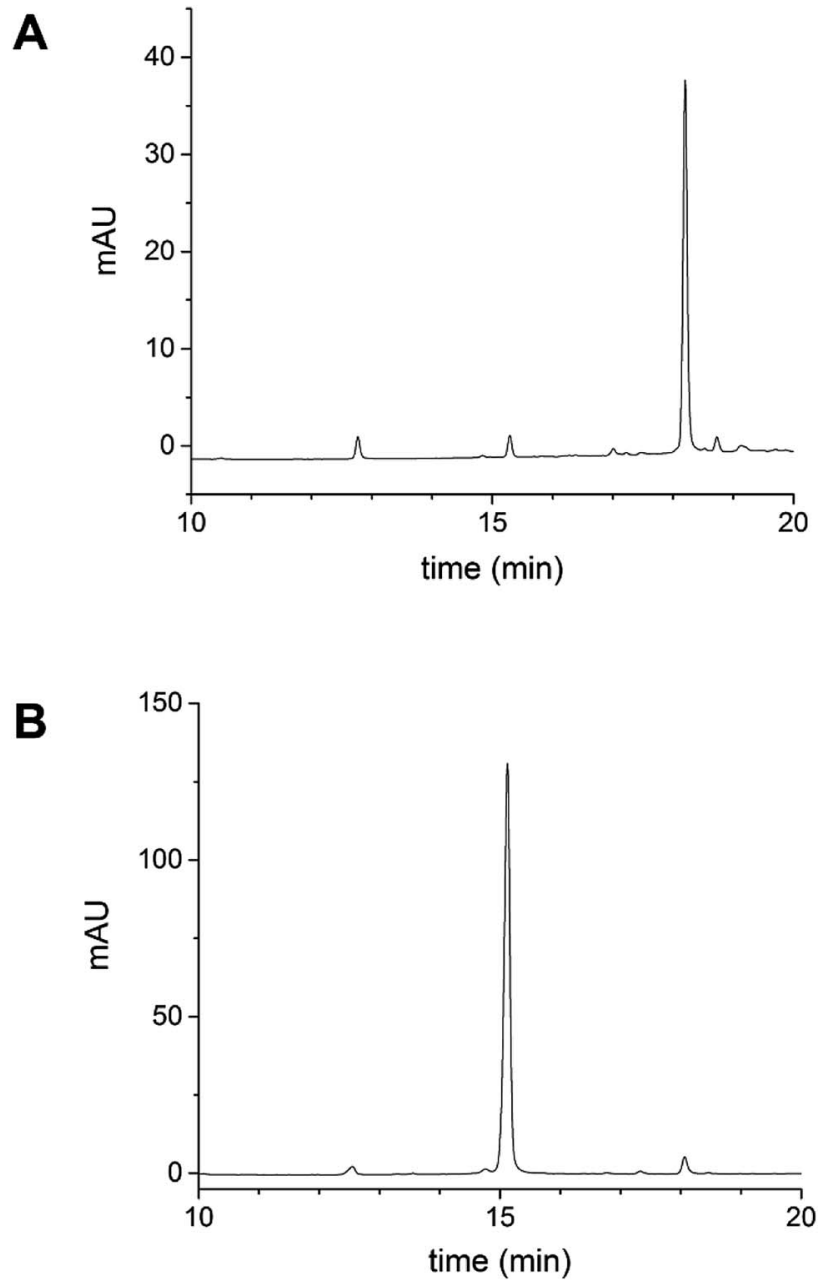

Fig. 7 Reverse-phase HPLC analysis of cur-SH and AaLS-IC-cur. (A) AaLS-IC-cur in PBS buffer was injected onto an analytical C4 HPLC column to check for non-covalently bound cur-SH in the AaLS-IC-cur sample. Under reverse-phase HPLC conditions, AaLS-IC protein should be denatured, allowing the separation of any noncovalent bound curcumin from the protein. (B) Pure cur-SH was subjected to the same HPLC analysis as a reference. The detection wavelength was $410 \mathrm{~nm}$.

Table 1 Solubility of free cur-SH and AaLS-IC-cur in aqueous buffer

\begin{tabular}{llll}
\hline Sample & $\begin{array}{c}\text { Theoretical }^{a} \\
{[\text { curcumin }](\mu \mathrm{M})}\end{array}$ & Pellet observed? $^{b}$ & $A_{412 \mathrm{~nm}^{c}}$ \\
\hline Cur-SH & 30 & Yes $^{d}$ & 0.156 \\
AaLS-IC-cur & 30 & No & 0.330 \\
AaLS-IC-cur & 86 & No & 1.383 \\
AaLS-IC-cur & 430 & No & $5.556^{e}$
\end{tabular}

${ }^{a}$ The theoretical [curcumin] represents the amount of cur-SH (either free or conjugated to AaLS-IC) expected in solution if the curcumin is fully soluble. The solvent is PBS buffer with $0.8 \%$ ethanol. ${ }^{b}$ The samples were subjected to centrifugation in $1.5 \mathrm{~mL}$ microcentrifuge tubes at $13000 \mathrm{rpm}$ for $5 \mathrm{~min}$ at room temperature in a Cence H1650 benchtop centrifuge. The bottoms of the tubes were then examined to check for insoluble material. ${ }^{c}$ After centrifugation, the supernatants were filtered through a $0.22 \mu \mathrm{m}$ membrane. The reported $A_{412} \mathrm{~nm}$ values correspond to the filtered supernatants. ${ }^{d}$ The pellet was yellow. ${ }^{e}$ After correction for a 2 -fold dilution. 
time points by reverse-phase HPLC showed the rapid accumulation of free cur-SH over the first two hours (Fig. 8A). Doubling the concentration of TCEP increased the apparent rate of cur-SH release over the first hour (Fig. 8B). In contrast, no free cur-SH
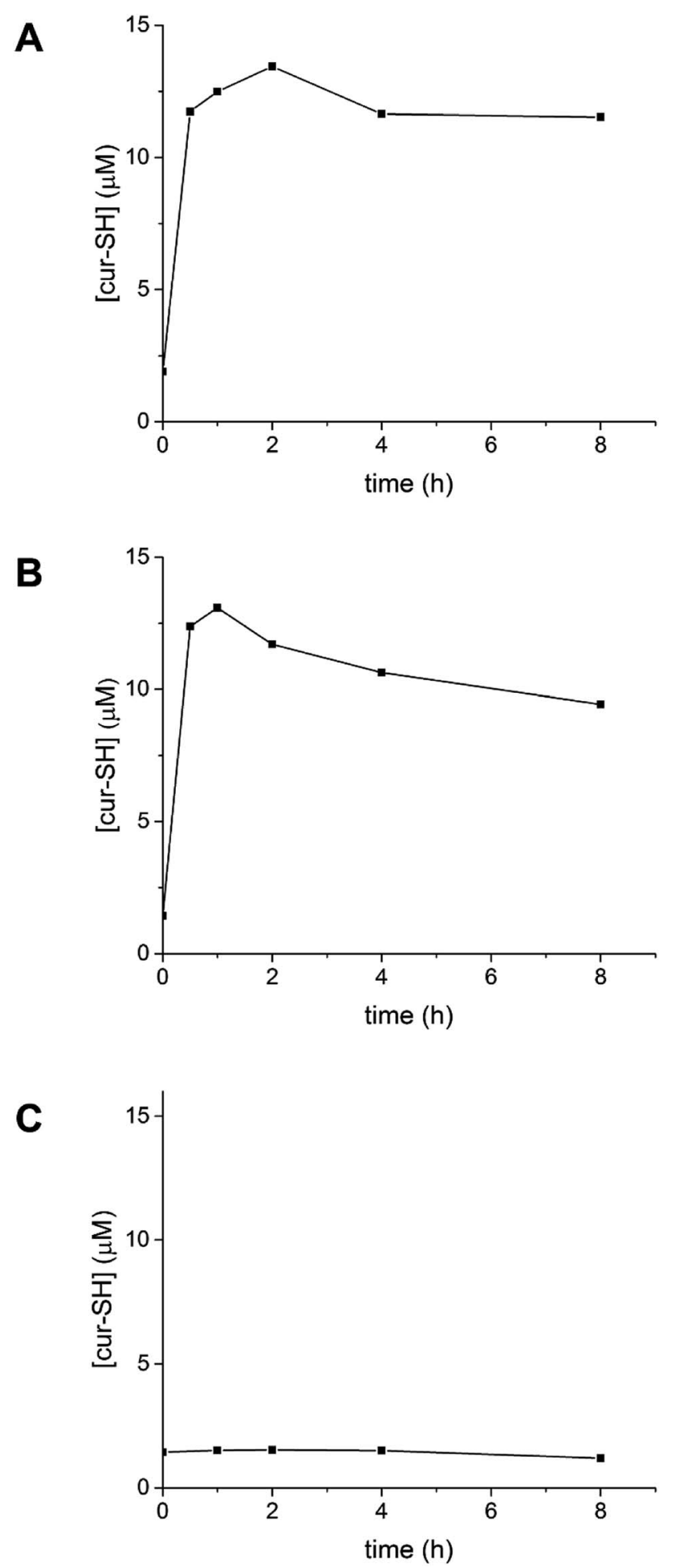

Fig. 8 Time course of cur-SH release from AaLS-IC-cur. AaLS-ICcur in PBS buffer was incubated with either $5 \mathrm{mM}$ TCEP (A), $10 \mathrm{mM}$ TCEP (B), or $0 \mathrm{mM} \mathrm{TCEP} \mathrm{(C)} \mathrm{at} 4{ }^{\circ} \mathrm{C}$ in the dark. The amount of free cur$\mathrm{SH}$ was measured over time using analytical HPLC. was apparent after $8 \mathrm{~h}$ in the negative control containing no TCEP (Fig. 8C). Together, these results demonstrate that cur-SH can be released from AaLS-IC capsid quickly, and that cur-SH release can be triggered by a reducing agent in a concentration-dependent manner.

Following the addition of $5 \mathrm{mM}$ TCEP to AaLS-IC-cur, the amount of free cur-SH reaches a maximum within $2 \mathrm{~h}$, after which the concentration slowly declines. A similar pattern is also observed for $10 \mathrm{mM}$ TCEP, although in this case the maximum concentration of free cur-SH occurs after only $1 \mathrm{~h}$. The maximum free cur-SH concentrations correspond to $66 \%$ and $80 \%$ of the covalently bound cur-SH in AaLS-IC-cur, for $5 \mathrm{mM}$ TCEP and $10 \mathrm{mM}$ TCEP, respectively. These yields indicate that the majority of the covalently bound cur-SH can be released from the capsid by TCEP.

Several other small-molecule encapsulation systems have previously been developed by engineering cysteine residues on the inner surfaces of virus capsids. For example, an engineered cysteine on the interior surface of the 180 subunit CCMV capsid was conjugated to a maleimide-derivatized spin label, which was used to probe structural changes associated with capsid swelling. ${ }^{46}$ Similarly, the bacteriophage MS2 capsid was labeled with a maleimide containing derivative of taxol with a yield of $65 \%{ }^{47}$ Using the same conjugation chemistry, this MS2 variant was also quantitatively loaded with porphyrin ${ }^{48}$ and an imaging agent. ${ }^{49}$ Likewise, engineered variants of the bacteriophage P22 capsid have been generated at various positions along the inner capsid surface that have been loaded with guests (including an imaging agent, a radical polymerization initiator, and a biotin derivative) bearing either maleimide or iodoacetamide functional groups with yields ranging from $50-100 \% . .^{20,50,51}$ The loading system used for AaLS-IC with cur-SH gives a yield in this range. The reaction between cysteine and maleimide or iodoacetamide produces a thioether bond, and thiol alkylation is generally irreversible. In contrast, disulfide bonds can be readily reduced under physiological conditions. The controlled release of the cargo molecules triggered by reduction extends the functional capability of this encapsulation system, which could be useful for applications such as drug delivery.

Given its broad array of pharmacological activities, there has been much interest in developing curcumin nanocarriers for drug delivery applications. Many different curcumin encapsulation systems have been reported, mostly based on noncovalent hydrophobic partitioning of curcumin into the nonpolar core of polymersomes, micelles, liposomes, solid lipid nanoparticles, or silica nanoparticles..$^{40,41}$ Recently, covalent conjugation strategies for attaching curcumin analogs to polymer-based micelles have been devised to provide triggered release of curcumin. Using a hydrazone linkage to methoxypoly(ethylene glycol)-poly(lactic acid) (mPEG-PLA) copolymers, curcumin analog loadings of $5-15 \%$ were reported in the resulting micelles. ${ }^{52}$ Upon lowering the $\mathrm{pH}$, the hydrazone was broken, releasing a maximum of $40-60 \%$ of the conjugated curcumin over $>10 \mathrm{~h}$. Similarly, an acetal conjugation between a curcumin analog and mPEG-PLA gave a loading yield of 7.1\% $(\mathrm{w} / \mathrm{w})$ in the resulting micelles and acidic release of $\sim 50 \%$ of the 
bound curcumin over $>30 \mathrm{~h} .{ }^{53}$ Similar to this study, a disulfide bond was also used to conjugate a curcumin analog to $\mathrm{mPEG}-$ PLA. ${ }^{35}$ The loading yield in the micelles was $8.2 \%(\mathrm{w} / \mathrm{w})$, and the bound curcumin could be released by reducing agents. In this case, the addition of $10 \mathrm{mM}$ DTT triggered about $50 \%$ of the curcumin to be released over $>30 \mathrm{~h}$. In comparison, the cur-SH content of AaLS-IC-cur is $2 \%(\mathrm{w} / \mathrm{w})$, however this apparently lower loading yield is mostly due to the higher molecular weight of the AaLS-IC polypeptide compared to the MPEG-PLA copolymer. For both the protein capsid and the polymeric micelle, each subunit of the nanoparticle assembly has one site for guest attachment and the majority of the subunits are conjugated to the guest after loading. The addition of TCEP to AaLS-IC-cur gives a somewhat higher maximum yield of released cur-SH, with much faster guest release, than the analogous mPEGPLA micelles. The more rapid guest release kinetics in the AaLSIC-cur system probably suggest that the disulfide bond connecting the cur-SH to AaLS-IC is relatively exposed compared to the disulfide bond in the analogous mPEG-PLA micelles, in which the curcumin analog and its conjugation site on the polymer are likely buried in the non-polar core of the particle, making them less accessible to reducing agents.

The decrease in free cur-SH at later time points could be caused by degradation of cur-SH. Indeed, previous studies have shown that curcumin is unstable in aqueous buffer ${ }^{37}$ and in the presence of free thiol groups. ${ }^{54}$ The mechanism of curcumin degradation is complex, and several pathways have been identified, many of which involve either nucleophilic attack at one of the carbonyl groups or a Michael-type addition at one of the adjacent $\alpha, \beta$ double bonds. ${ }^{55}$ Both the thiol group of cur-SH and the phosphine of TCEP could conceivably promote curcumin degradation after the release of cur-SH from the AaLS-IC capsid. To examine whether TCEP causes degradation of cur-SH, the absorbance of free cur-SH at $412 \mathrm{~nm}$ was measured over time in the presence and absence of $10 \mathrm{mM}$ TCEP. In the absence of TCEP, the absorbance of cur-SH decreases by about $15 \%$ over $2 \mathrm{~h}$ at $\mathrm{pH} 8.0$ (90\% SEC buffer $/ 10 \%$ ethanol) and room temperature (Fig. 9). Cur-SH lost absorbance much more rapidly in the presence of $10 \mathrm{mM}$ TCEP, with only about $30 \%$ of its original absorbance remaining after $2 \mathrm{~h}$. Although the cur-SH release experiments described above were carried out at lower $\mathrm{pH}$ and temperature conditions, at which the reaction of cur-SH with TCEP is likely somewhat slower, the decreased yield of free cur-SH observed at later time points (Fig. 8B) can be attributed to this type of degradation, given that the HPLC detection of cur-SH was also done at $410 \mathrm{~nm}$.

The addition of TCEP to AaLS-IC-cur causes free cur-SH to accumulate rapidly (Fig. 8), suggesting that reduction of the disulfide bond in the AaLS-IC-cur conjugate is faster than cur$\mathrm{SH}$ degradation. Over time, however, the accumulated free cur-SH degrades. Although initially this degradation is compensated for by the continuing reductive release of cur-SH from the capsid, eventually the supply of AaLS-IC-cur conjugates becomes depleted, the cur-SH degradation rate overtakes the cur-SH release rate, and the concentration of free cur-SH declines. Thus, the maximum observed yields for cur-SH

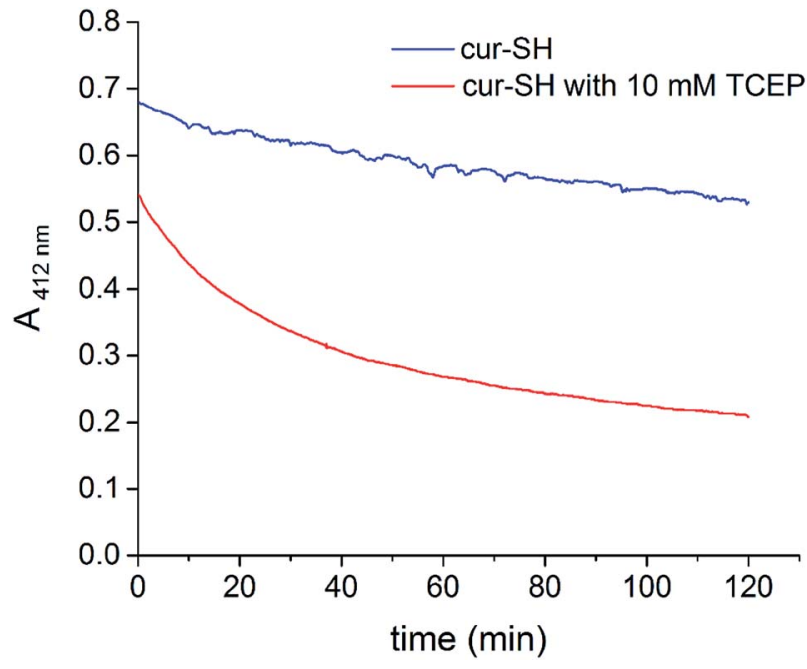

Fig. 9 Time course of cur-SH degradation. The absorbance at $412 \mathrm{~nm}$ of cur-SH in SEC buffer with 10\% ethanol was measured over $2 \mathrm{~h}$ in the presence (red) and absence (blue) of TCEP.

release $(66 \%$ and $80 \%$ for $5 \mathrm{mM}$ TCEP and $10 \mathrm{mM}$ TCEP, respectively) represent lower limits for the reduction of the disulfide bond in AaLS-IC-cur. For other potential guests that are not susceptible to degradation by TCEP, the yield of guest release would likely be even higher.

\section{Conclusions}

To encapsulate small molecules, a reactive cysteine was installed at the interior surface the AaLS capsid. A novel thioldisulfide exchange process was carried out at this interior cysteine which lead to the capture of the 41 cur-SH molecules per capsid. Cur-SH can be released from the AaLS-IC capsid by treatment with the reducing agent TCEP. This reductive release mechanism may be a useful feature for applications such as drug delivery, as the reducing environment of the cytosol could potentially trigger drug release in the cell. In addition, encapsulated cur-SH demonstrated a marked improvement in aqueous solubility, suggesting that its encapsulation within AaLS-IC might improve its bioavailability for drug delivery applications. This system may be generally useful for encapsulation of small molecules containing a thiol group and could also be easily extended to the capture of cargo molecules that possess electrophilic groups.

\section{Acknowledgements}

We thank Prof. Bob Borris for technical assistance and advice regarding the HPLC experiments. Prof. Nat Finney graciously provided access to the fluorimeter used to obtain the emission spectra. We are grateful to Profs. Yanjun Zhao and Zheng Wang for helpful discussions and technical assistance with the synthesis of cur-SH. Funding for this research was provided by Tianjin University and the University of Utah. 


\section{References}

1 M. Uchida, M. Young and T. Douglas, Adv. Mater., 2007, 19, 1025-1042.

2 T. W. Giessen and P. A. Silver, J. Mol. Biol., 2016, 428, 916927.

3 J. A. Speir and J. E. Johnson, Curr. Opin. Struct. Biol., 2012, 22, 65-71.

4 X. Liu and E. C. Theil, Acc. Chem. Res., 2005, 38, 167-175.

5 T. A. Bobik, B. P. Lehman and T. O. Yeates, Mol. Microbiol., 2015, 98, 193-207.

6 M. Sutter, D. Boehringer, S. Gutmann, S. Gunther, D. Prangishvili, M. J. Loessner, K. O. Stetter, E. Weber-Ban and N. Ban, Nat. Struct. Mol. Biol., 2008, 15, 939-947.

7 R. Ladenstein, M. Fischer and A. Bacher, FEBS J., 2013, 280, 2537-2563.

8 D. Peer, J. M. Karp, S. Hong, O. C. Farokhzad, R. Margalit and R. Langer, Nat. Nanotechnol., 2007, 2, 751-759.

9 R. M. Putri, J. J. Cornelissen and M. S. T. Koay, ChemPhysChem, 2015, 16, 911-918.

10 L. Schoonen and J. C. M. van Hest, Adv. Mater., 2016, 28, 1109-1128.

11 Z. P. Sahandi, M. Karimi, F. Mehidizadeh, A. Ghasemi, S. Bahrami, H. Zare, M. Moghoofei, A. Hekmatmanesh and M. R. Hamblin, Nanoscale, 2017, 9, 1356-1392.

12 Y. Zhang, M. S. Ardejani and B. P. Orner, Chem.-Asian J., 2016, 11, 2814-2828.

13 R. L. Garcea and L. Gissmann, Curr. Opin. Biotechnol., 2004, 15, 513-517.

14 E. Strable and M. G. Finn, Curr. Top. Microbiol. Immunol., 2009, 327, 1-21.

15 Z. Wu, K. Chen, I. Yildiz, A. Dirksen, R. Fischer, P. E. Dawson and N. F. Steinmetz, Nanoscale, 2012, 435, 67-76.

16 Y. Ma, R. J. Nolte and J. J. Cornelissen, Adv. Drug Delivery Rev., 2012, 64, 811-825.

17 E. W. Kovacs, J. M. Hooker, D. W. Romanini, P. G. Holder, K. E. Berry and M. B. Francis, Bioconjugate Chem., 2007, 18, 1140-1147.

18 D. Banerjee, A. P. Liu, N. R. Voss, S. L. Schmid and M. G. Finn, ChemBioChem, 2010, 11, 1273-1279.

19 J. D. Fiedler, S. D. Brown, J. L. Lau and M. G. Finn, Angew. Chem., Int. Ed., 2010, 49, 9648-9651.

20 M. Uchida, D. S. Morris, S. Kang, C. C. Jolley, J. Lucon, L. O. Liepold, B. LaFrance, P. E. J. Prevelige and T. Douglas, Langmuir, 2012, 28, 1998-2006.

21 A. Abbing, U. K. Blaschke, S. Grein, M. Kretschmar, C. M. B. Stark, M. J. W. Thies, J. Walter, M. Weigand, D. C. Woith, J. Hess and C. O. A. Reiser, J. Biol. Chem., 2004, 279, 27410-27421.

22 X. Lu, J. R. Thompson and K. L. Perry, J. Gen. Virol., 2012, 93, 1120-1126.

23 M. Kwak, I. J. Minten, D. M. Anaya, A. J. Musser, M. Brasch, R. J. Nolte, K. Müllen, J. J. Cornelissen and A. Herrmann, J. Am. Chem. Soc., 2010, 132, 7834-7835.

24 I. J. Minten, L. J. Hendriks, R. J. Nolte and J. J. Cornelissen, J. Am. Chem. Soc., 2009, 131, 17771-17773.
25 P. A. Suci, Z. Varpness, E. Gillitzer, T. Douglas and M. Young, Langmuir, 2007, 23, 12280-12286.

26 X. Zhang, W. Meining, M. Fischer, A. Bacher and R. Ladenstein, J. Mol. Biol., 2001, 306, 1099-1114.

27 H.-N. Chen and K. J. Woycechowsky, Biochemistry, 2012, 51, 4704-4712.

28 R. Ladenstein, K. Ritsert, R. Huber, G. Richter and A. Bacher, Eur. J. Biochem., 1994, 223, 1007-1017.

29 S. Lilavivat, D. Sardar, S. Jana, G. C. Thomas and K. J. Woycechowsky, J. Am. Chem. Soc., 2012, 134, 1315213155.

30 Y. Azuma, R. Zschoche, M. Tinzl and D. Hilvert, Angew. Chem., Int. Ed., 2016, 55, 1531-1534.

31 R. Frey, S. Mantri, M. Rocca and D. Hilvert, J. Am. Chem. Soc., 2016, 138, 10072-10075.

32 F. P. Seebeck, K. J. Woycechowsky, W. Zhuang, J. P. Rabe and D. Hilvert, J. Am. Chem. Soc., 2006, 128, 4516-4517.

33 B. Wörsdörfer, K. J. Woycechowsky and D. Hilvert, Science, 2011, 331, 589-592.

34 B. Wörsdörfer, Z. Pianowski and D. Hilvert, J. Am. Chem. Soc., 2012, 134, 909-911.

35 Y. Cao, M. Gao, C. Chen, A. Fan, J. Zhang, D. Kong, Z. Wang, D. Peer and Y. Zhao, Nanotechnology, 2015, 26, 115101.

36 P. W. Riddles, R. L. Blakeley and B. Zerner, Methods Enzymol., 1983, 91, 49-60.

37 O. Naksuriya, M. J. van Steenbergen, J. S. Torano, S. Okonogi and W. E. Hennink, AAPS J., 2015, 18, 777-787.

38 H. H. Tønnesen, M. Másson and T. Loftsson, Int. J. Pharm., 2002, 244, 127-135.

39 B. B. Aggarwal and K. B. Harikumar, Int. J. Biochem. Cell Biol., 2009, 41, 40-59.

40 S. Shome, A. D. Talukdar, M. D. Choudhury, M. K. Bhattacharya and H. Upadhyaya, J. Pharm. Pharmacol., 2016, 68, 1481-1500.

41 M. Mehanny, R. M. Hathout, A. S. Geneidi and S. Mansour, J. Controlled Release, 2016, 225, 1-30.

42 G. L. Ellman, Arch. Biochem. Biophys., 1959, 82, 70-77.

43 S. H. Kim, S. Y. Gwon, S. M. Burkinshaw and Y. A. Son, Spectrochim. Acta, Part A, 2010, 76, 384-387.

44 S. Mondal, S. Ghosh and S. P. Moulik, J. Photochem. Photobiol., B, 2016, 158, 212-218.

45 Z. Stanic, Plant Foods Hum. Nutr., 2017, 72, 1-12.

46 R. J. Usselman, E. D. Walter, D. Willits, T. Douglas, M. Young and D. J. Singel, J. Am. Chem. Soc., 2011, 133, 4156-4159.

47 W. Wu, S. C. Hsiao, Z. M. Carrico and M. B. Francis, Angew. Chem., Int. Ed., 2009, 48, 9493-9497.

48 N. Stephanopoulos, G. J. Tong, S. C. Hsiao and M. B. Francis, ACS Nano, 2010, 4, 6014-6020.

49 P. D. Garimella, A. Datta, D. W. Romanini, K. N. Raymond and M. B. Francis, J. Am. Chem. Soc., 2011, 133, 1470414709.

50 J. Lucon, S. Qazi, M. Uchida, G. J. Bedwell, B. LaFrance, P. E. Prevelige and T. Douglas, Nat. Chem., 2012, 4, 781788.

51 S. Kang, M. Uchida, A. O'Neil, R. Li, P. E. Prevelige and T. Douglas, Biomacromolecules, 2010, 11, 2804-2809. 
52 M. Gao, C. Chen, A. Fan, J. Zhang, D. Kong, Z. Wang and Y. Zhao, Nanotechnology, 2015, 26, 275101.

53 M. Li, M. Gao, Y. Fu, C. Chen, X. Meng, A. Fan, D. Kong, Z. Wang and Y. Zhao, Colloids Surf., B, 2016, 140, 11-18.
54 S. Amslinger, N. Al-Rifai, K. Winter, K. Wörmann, R. Scholz, P. Baumeister and M. Wild, Org. Biomol. Chem., 2013, 11, 549-554.

55 M. Heger, R. F. van Golen, M. Broekgaarden and M. C. Michel, Pharmacol. Rev., 2013, 66, 222-307. 